\title{
上斜筋麻痷に対する下直筋水平移動術
}

\author{
野島 祥代・小原真樹夫・清水 公也
}

武蔵野赤十字病院眼科

\section{Horizontal Transposition of the Inferior Rectus Muscle for Superior Oblique Palsy}

\author{
Sachiyo Nojima, Makio Kohara, Kimiya Shimizu \\ Department of Ophthalmology, Musashino Red-Cross Hospital
}

\begin{abstract}
要 約
両側性の上斜筋麻痺の症例に対して, von Noordenの原法に準じた片眼の下直筋の水平移動術を 行ない，良好な結果を得たので報告した。症例は31歳の男性で，回旋性の複視を訴え，両眼の外方 回旋， $\mathrm{V}$ 型内斜視などより、両眼性の上斜筋麻疸と診断し，左眼の下直筋の鼻側移動術を行った。術 眼において外方回旋は正面視 $5^{\circ}$ ，下方視 $10^{\circ}$ の改善がえられ，術前に正面視，下方視で自覚され た回旋複視は右下方視以外は解消された。現在，外方回旋斜視に対しては上斜筋前部前転などの上 斜筋強化手術が行なわれることが多いと考えられるが，今回行なった下直筋の鼻側への水平移動は, 症例によっては今後選択してよい術式と考えられた。
\end{abstract}

Abstract

A 31-year-old male with bilateral superior oblique palsy, who complained of torsional diplopia, underwent von Noorden's horizontal transposion of the vertical rectus muscle. Ocular motility was full in all direction, but excyclotropia and V-pattern esotropia were observed before surgery. Nasal transpositon of the inferior rectus muscle of the left eye was performed. The effect was a correction of 3 degree in upward position, 5 degree in primary position and 7 degree in downward position in the treated eye. Torsional diplopia, formerly present in primary position and downward gaze, was limited to right downward gaze after surgery. Although the advancement of the anterior portion of the superior oblique tendon has become an accepted mode of treatment for excyclotropia, nasal transposition of the inferior rectus muscle is a viable choice.

連絡先（广180-0023）東京都武蔵野市境南町一丁目26番 1 号

武蔵野赤十字病院眼科 野 島 祥 代

Tel. $0422-32-3111$

Key words : superior oblique palsy, transposition of the vertical muscle 


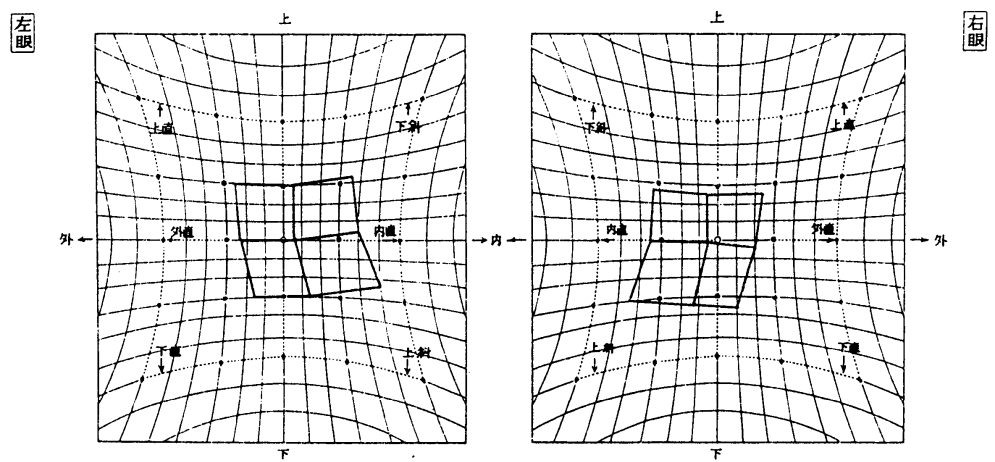

図 1 . 術前のHess 赤緑検査

\section{I 。緒言}

眼筋麻瘏の中で，上斜筋麻瘏は頻度も高く, 日常診療で遭遇する機会が多い。片眼性の上斜 筋麻瘦では眼球は上斜視, 内斜視, 外方回旋斜 視を起こすが, 両眼性の場合は外見上の眼球運 動制限は著明でなく，両眼の外方回旋斜視が主 となることが多く, 回旋複視, 頭位異常などを 訴える場合には手術的な治療の対象となる。上 斜筋麻疸の手術では従来は拮抗筋である下斜筋 を弱化するか, 麻痷筋である上斜筋を強化する ことが多かった。von Noorden らは回旋偏位に 対し, 上下の直筋の水平移動を行ない, その有 用性を述べている ${ }^{\prime \prime}$ 。われわれも雨眼の上斜筋 麻痷による回旋複視を訴える症例に, 片眼の下 直筋の鼻側への水平移動を行ない, 自覚症状の 軽減が得られたので報告する。

\section{II. 症例}

症例：31歳, 男性。

主訴：回旋性の複視。

現病歴：1996年8月22日, ベランダより転落し て, 意識消失し, 当院脳神経外科入院。意識回 復後, 正面視, 下方視での複視を自覚し，10月 14日眼科受縞。

腿科的所見：視彦にてあご引き頭位をとって いた。眼位は证而視では正:位。眼球連動はひき 迎動，むき連動とも制限はなかった。Hess赤緑 検査では，V型の内斜視と左眼の上斜視を認め た（図 1 )。シノプトフォアでの眼位は，右眼
固視において上方視 $20^{\circ}$ で $6^{\circ}$ 内斜視，正面視 で $8^{\circ}$ 内斜視, 下方視 $20^{\circ}$ で $10^{\circ}$ の内斜視と, 上下での眼位差 $4^{\circ}$ のV型内斜視を認めた。 9 方向すべてで外方回旋斜視を呈し，下方視では $20^{\circ}$ 以上となった。上下偏位は $2^{\circ}$ 以下の左眼 の上斜視であった（図 $2 \mathrm{a}$ )。左眼固視でも上下 の眼位差 $5^{\circ}$ のV型内斜視， 9 方向すべてでの

\begin{tabular}{|c|c|c|c|c|c|}
\hline $\begin{array}{c}5^{\circ} \mathrm{ET} \\
0^{\circ} \mathrm{L} / \mathrm{R}\end{array}$ & $\begin{array}{l}7^{\circ} \\
\text { EX }\end{array}$ & $\begin{array}{c}6^{\circ} \mathrm{ET} \\
0^{\circ} \mathrm{L} / \mathrm{R}\end{array}$ & $\begin{array}{l}7^{\circ} \\
\text { EX }\end{array}$ & $\begin{array}{cc}5^{\circ} \mathrm{ET} \\
1^{\circ} \mathrm{L} / \mathrm{R}\end{array}$ & $\begin{array}{l}7^{\circ} \\
\text { EX }\end{array}$ \\
\hline $\begin{array}{c}5^{\circ} \mathrm{ET} \\
2^{\circ} \mathrm{L} / \mathrm{R}\end{array}$ & $\begin{array}{r}12^{\circ} \\
\text { EX }\end{array}$ & $\begin{array}{c}8^{\circ} \mathrm{ET} \\
1^{\circ} \mathrm{L} / \mathrm{R}\end{array}$ & $\begin{array}{r}11^{\circ} \\
\text { EX }\end{array}$ & $\begin{array}{c}6^{\circ} \cdot \text { ET } \\
0^{\circ} \mathrm{L} / \mathrm{R}\end{array}$ & $\begin{array}{r}11^{\circ} \\
\text { EX }\end{array}$ \\
\hline $\begin{array}{l}11^{\circ} \mathrm{ET} \\
2^{\circ} \mathrm{L} / \mathrm{R}\end{array}$ & $\begin{array}{r}21^{\circ} \\
\text { EX }\end{array}$ & $\begin{array}{l}10^{\circ} \mathrm{ET} \\
1^{\circ} \mathrm{L} / \mathrm{R}\end{array}$ & $\begin{array}{r}20^{\circ} \\
\text { EX }\end{array}$ & $\begin{array}{cc}7^{\circ} \mathrm{ET} \\
0^{\circ} \mathrm{L} / \mathrm{R}\end{array}$ & $\begin{array}{r}22^{\circ} \\
\text { EX }\end{array}$ \\
\hline
\end{tabular}

右方視

左方視

図 2 a. シノプトフォアによる術前の 9 方向眼位 （右眼固視）

\begin{tabular}{|cr|cr|cr|}
\hline $7^{\circ} \mathrm{ET}$ & $16^{\circ}$ & $4^{\circ} \mathrm{ET}$ & $13^{\circ}$ & $5^{\circ} \mathrm{ET}$ & $13^{\circ}$ \\
$4^{\circ} \mathrm{L} / \mathrm{R}$ & $\mathrm{EX}$ & $4^{\circ} \mathrm{L} / \mathrm{R}$ & $\mathrm{EX}$ & $4^{\circ} \mathrm{L} / \mathrm{R}$ & $\mathrm{EX}$ \\
\hline $8^{\circ} \mathrm{ET}$ & $16^{\circ}$ & $8^{\circ} \mathrm{ET}$ & $16^{\circ}$ & $7^{\circ} \mathrm{ET}$ & $17^{\circ}$ \\
$3^{\circ} \mathrm{L} / \mathrm{R}$ & $\mathrm{EX}$ & $3^{\circ} \mathrm{L} / \mathrm{R}$ & $\mathrm{EX}$ & $5^{\circ} \mathrm{L} / \mathrm{R}$ & $\mathrm{EX}$ \\
\hline $9^{\circ} \mathrm{ET}$ & $23^{\circ}$ & $9^{\circ} \mathrm{ET}$ & $25^{\circ}$ & $12^{\circ} \mathrm{ET}$ & $25^{\circ}$ \\
$3^{\circ} \mathrm{L} / \mathrm{R}$ & $\mathrm{EX}$ & $5^{\circ} \mathrm{L} / \mathrm{R}$ & $\mathrm{EX}$ & $6^{\circ} \mathrm{L} / \mathrm{R}$ & $\mathrm{EX}$ \\
\hline
\end{tabular}

右方視

左方視

図 2 b. シノプトフォアによる術前の 9 方向眼位 (左眼固視) 
外方回旋斜視，上下偏位 $6^{\circ}$ 以下の上斜視と同 じ傾向を示した（図 $2 b$ ）。また頭位の傾きに注 意して，片眼遮蔽にて開放眼に残像法用スライ ドを固視させて，左右各一眼ずつの回旋を自覚 的に测定したところ，左右各眼とも全方向で外 方回旋斜視が認められ，下方視で增大した。 Bielschowsky Head Tilt Testは左右とも陰性で あった。

経過：Hess 赤緑検査で $\mathrm{V}$ 型の斜視, シノプト

\section{左眼}

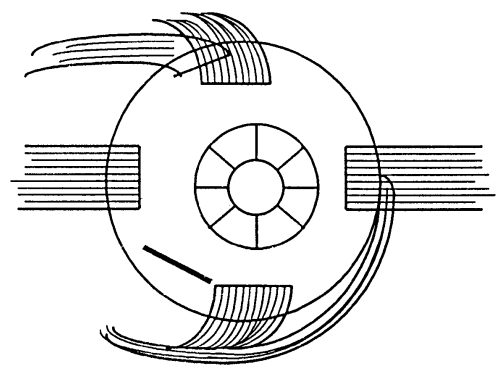

図 3.下直筋の移動位置
フォアで両眼外方回旋斜視がみられたことから 而侧性の上斜筋麻㽻と診断し, 経過観察してい たが, 自覚症状, 他覚的所見に変化ないため, 受管約 8 ヶ月後の1997年 6 月27日に，左下直筋 の帠侧への水平移動術を行った。von Noorden 1) の原法に準じて下直筋を腱の幅の分水平方向 に移動した（図 3 )。術前に正面視および下方 視すべてで見られた複視は右下方視のみとなり， あご引き頭位は解消された。Hess赤緑検査では $\mathrm{V}$ 型の斜視は大きな変化はなかったが，右方視 での左眼の上斜視が顕著になった（図 4)。シ ノプトフォアでは外方回旋は 9 方向すべてで減 少し，右眼固視では正面視で $5^{\circ}$ ，下方視で $10^{\circ}$, 左眼固視では正面視で $6^{\circ}$ ，下方視で $13^{\circ}$ の改善が得られた。それに反して上下の斜 視は9方向すべてで大きくなり，正面視で右眼固 視左眼固視共に $3^{\circ}$ の左眼の上斜を認め, 右方 視で増強した。内斜視については術前に比べ, 大きな変化はなかった（図 $5 \mathrm{a} ，$ 図 $5 \mathrm{~b}$ )。
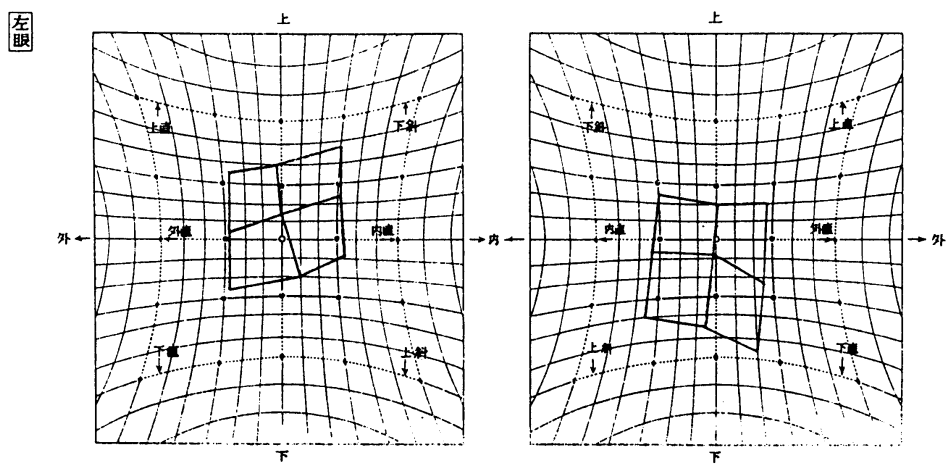

奋

図 4. 術後のHess 赤緑検査

\begin{tabular}{|cc|cc|cc|}
\hline $3^{\circ} \mathrm{ET}$ & $2^{\circ}$ & $4^{\circ} \mathrm{ET}$ & $2^{\circ}$ & $4^{\circ} \mathrm{ET}$ & $0^{\circ}$ \\
$6^{\circ} \mathrm{L} / \mathrm{R}$ & $\mathrm{EX}$ & $5^{\circ} \mathrm{L} / \mathrm{R}$ & $\mathrm{EX}$ & $2^{\circ} \mathrm{L} / \mathrm{R}$ & $\mathrm{EX}$ \\
\hline $1^{\circ} \mathrm{ET}$ & $3^{\circ}$ & $6^{\circ} \mathrm{ET}$ & $6^{\circ}$ & $3^{\circ} \mathrm{ET}$ & $4^{\circ}$ \\
$10^{\circ} \mathrm{L} / \mathrm{R}$ & $\mathrm{EX}$ & $4^{\circ} \mathrm{L} / \mathrm{R}$ & $\mathrm{EX}$ & $3^{\circ} \mathrm{L} / \mathrm{R}$ & $\mathrm{EX}$ \\
\hline $5^{\circ} \mathrm{ET}$ & & $10^{\circ} \mathrm{ET}$ & $10^{\circ}$ & $4^{\circ} \mathrm{ET}$ & \\
$14^{\circ} \mathrm{L} / \mathrm{R}$ & $\mathrm{EX}$ & $12^{\circ} \mathrm{L} / \mathrm{R}$ & $\mathrm{EX}$ & $2^{\circ} \mathrm{L} / \mathrm{R}$ & $\mathrm{EX}$ \\
\hline
\end{tabular}

右方視 左方視

図 5 a. シノプトフォアによる術後の 9 方向眼位 (右眼固視)

\begin{tabular}{|cc|ccc|cc|}
\hline $5^{\circ}$ & ET & $5^{\circ}$ & $4^{\circ}$ ET & $7^{\circ}$ & $5^{\circ}$ ET & $7^{\circ}$ \\
$7^{\circ} \mathrm{L} / \mathrm{R}$ & $\mathrm{EX}$ & $4^{\circ} \mathrm{L} / \mathrm{R}$ & $\mathrm{EX}$ & $2^{\circ} \mathrm{L/R}$ & $\mathrm{EX}$ \\
\hline $6^{\circ} \mathrm{ET}$ & $8^{\circ}$ & $5^{\circ} \mathrm{ET}$ & $10^{\circ}$ & $2^{\circ} \mathrm{ET}$ & $7^{\circ}$ \\
$12^{\circ} \mathrm{L} / \mathrm{R}$ & $\mathrm{EX}$ & $6^{\circ} \mathrm{L} / \mathrm{R}$ & $\mathrm{EX}$ & $1^{\circ} \mathrm{L} / \mathrm{R}$ & $\mathrm{EX}$ \\
\hline $8^{\circ} \mathrm{ET}$ & & $9^{\circ} \mathrm{ET}$ & $12^{\circ}$ & $5^{\circ} \mathrm{ET}$ & \\
$10^{\circ} \mathrm{L} / \mathrm{R}$ & $\mathrm{EX}$ & $10^{\circ} \mathrm{L} / \mathrm{R}$ & $\mathrm{EX}$ & $1^{\circ} \mathrm{L} / \mathrm{R}$ & $\mathrm{EX}$ \\
\hline
\end{tabular}

右方視

左方視

図 5 b. シノプトフォアによる術後の 9 方向眼位 (左眼固視) 


\section{III. 考按}

上斜筋麻瘏での眼球偏位の方向は, 上斜視, 内斜視，外方回旋斜視となるが，手術の対象と なるのは主として上下斜視と外方回旋斜視の場 合と考えられる。上下斜視に対しては，患眼の 上直筋後転, 健眼の下直筋後転などが行なわれ ている。外方回旋斜視に対しては拮抗筋である 下斜筋の弱化手術として筋部分切除術, 後転術 などが，また麻痺筋である上斜筋の強化手術と して腱縫縮術, 腱前部前転術 (Harada-Ito procedure） ${ }^{2)}$ などが行なわれてきた ${ }^{31}$ 。下斜筋 弱化手術は続発性の下斜筋過動に対するもので あるので, 本症例のように下方視での回旋複視 を訴える症例には適当でないと考えられる。上 斜筋麻痺に対するKnapp分類 ${ }^{4}$ に従えば本症例 のような両側の上斜筋麻瘏はClass VI になり, 両側の上斜筋強化手術が適応とされる。

上斜筋強化手術の過去の手術成績を回旋偏位 の矯正効果でみてみると, 腱縫縮術では中山 ${ }^{5}$ の $2^{\circ} \sim 19^{\circ}$, 井嵭ら ${ }^{6} 94^{\circ} \sim 20^{\circ}$, 腱前部 前転術では大月ら"の $10^{\circ} \sim 12^{\circ}$, 丸尾 ${ }^{8)}$ の $10.2^{\circ} \pm 4.0^{\circ}$ などの報告がある。手術定量につ いては一定の見解は得られていないが, 現時点 では回旋偏位の矯正には腱前部前転術が上下偏 位に影響を与えることが少なく，一般的と考え

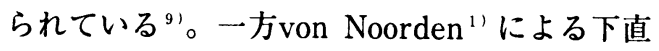
筋の水平移動では外方回旋斜視の矯正効果は, 正面視では, $2^{\circ} \sim 10^{\circ}$ (平均 $6^{\circ}$ ), 下方視 では $3^{\circ} \sim 15^{\circ}$ (平均 $7^{\circ}$ ) であり ${ }^{\prime}$, 今回の われわれの症例も右眼固視のシノプトフォアで は正面視で $5^{\circ}$, 下方視で $10^{\circ}$ の回旋の減少を みており, 自覚的にも頭位の改善, 回旋複視の 軽減が得られた。下直筋の鼻側への水平移動は 下直筋の外方回旋を弱化させることになり, 眼 球の内方回旋が得られるものと考えられる。

今回行なった下直筋の水平移動術は回旋角度 の矯正量は上斜筋強化手術と比較すると少ない が, 患者の回旋複視に対する訴えの解消, それ に伴う顽位暴常の消失が今回の乎術の評価され る点であると言える。更に上斜筋手術に比べ過 矯正の心配は少なく, その場合も対処しやすい と考えられる。
上斜筋手術は定量の難しさや直筋に比べて手 術が煩雑であることなどから，上斜筇麻疸と診 断しても手術は敬遠されがちであった。上斜筋 に対する手術は，球後麻酔，鎮痛剂の併用なと で行われていることが多いが(1)，今回用いた手 術は点眼麻酔のみで十分行うことが出来, 患者 の苦痛も少ないと考えられる。また内方回旋斜 視に対しても上直筋に対して同様に鼻側への移 動を行うことで対処できるのは大きな利点と思 われる。後天性上斜筋麻痺に上斜筋縫縮を行う と必発とされる医原性Brown 症候群について von Noorden"1特に対策は述べていないが, 術眼の上直筋後転などで対処する必要があると 考えられる。術後生じる上斜視を防ぐには下直 筋の移動量を変える, 両眼に振り分けて移動さ せるなどが対策として考えられる。これらは今 後の検討課題と思われる。

\section{参考文献}

1) von Norden G K , et al : Horizontal transposition of the vertical rectus muscle for cyclotropia. Am J Ophthalmol :122 : 325330, 1996

2) Harada $M$, et al : Surgical correction of cyclotropia. Jpn J Ophthalmol :8:88-96, 1964

3 ）矢ヶ崎悌司：斜筋手術. 眼科手術 $9: 463$ 474, 1966.

4) Knapp P :Classification and treatment of superior oblique palsy. Am Orthop J 24:1822,1974 .

5 ）中山緑子：運動性回旋融像の研究. 第3 報 上 斜筋麻㿉における上斜筋縫縮術の効果. 日眼 $91: 807-814,1987$.

6 ）井㠃篤子, 他 : 上斜筋麻㾝 23 症例の臨床的検 討. 眼紀 $40: 2464-2470,1989$.

7 ) 大月洋, 他：外傷性両側滑車神経麻瘇に対す る上斜筋前部前転術. 日眼95：288-293, 1991.

8 ）丸尾敏夫：上斜筋麻痺の乎術. 眼臨84：15431552.

9 ）大月洋, 他：上下斜視・眼筋麻痺の治燎, 141-142, 金原出版, 東京, 1984.

10）岩重博康：斜視手術の基本術式と量定一回旋 
偏位矯正術, 丸尾敏夫（編）：眼科プラクテ イス 4，152-154, 文光堂, 東京, 1993.

質問

(座長 東 範行)

1.上下に対する複視の訴えはどうでしたか？

\section{答弁}

1. 術後 5 カ月の時点で, 上下の複視についての 訴えはきておりません。術前も回旋の複視が 強かったためか, 上下の複視はあまり気にな らなかったようです。 